Marquette University

e-Publications@Marquette

$1-1-2003$

\title{
Should Marketing Managers Be Concerned about Attitudes towards Marketing and Consumerism in New Zealand: A Longitudinal View
}

\author{
Steven Lysonski \\ Marquette University, steven.lysonski@marquette.edu \\ Srinivas Durvasula \\ Marquette University, srinivas.durvasula@marquette.edu \\ John Watson \\ Marquette University
}

Accepted version. European Journal of Marketing, Volume 37, Issue 3/4, pp 385-406 (2003). DOI. This article is (C) Emerald Group Publishing and permission has been granted for this version to appear in e-Publications@Marquette. Emerald does not grant permission for this article to be further copied/distributed or hosted elsewhere without the express permission from Emerald Group Publishing Limited. 


\title{
Should marketing managers be concerned about attitudes towards marketing and consumerism in New Zealand? A longitudinal view
}

\author{
Steven Lysonski \\ Department of Management, \\ University of Canterbury \\ Christchurch, New Zealand \\ Srinivas Durvasula \\ Department of Management, \\ University of Canterbury \\ Christchurch, New Zealand \\ John Watson \\ Marketing Department, Marquette University \\ Milwaukee, WI
}

\begin{abstract}
:
New Zealand has gone through a radical metamorphosis since free market economics were introduced in the mid-1980s. Marketing managers are particularly interested in the views of consumers about issues dealing with marketing activities. Negative views could signal consumer backlash against free market activities. This study examines the views of consumers from 1986 to 2001 on a range of issues dealing with marketing and consumerism. The results clearly show that consumers are less negative about marketing and consumerism issues since 1986. It seems likely that New Zealand has evolved in terms of the consumerism life cycle over the last 15 years. Marketing managers should continue to remain proactive in their responses to consumer
\end{abstract}


NOT THE PUBLISHED VERSION; this is the author's final, peer-reviewed manuscript. The published version may be accessed by following the link in the citation at the bottom of the page.

discontents. Implications for New Zealand and for other countries are addressed.

Keywords: Marketing, Management, Consumer attitudes, Consumerism, New Zealand.

\section{Introduction}

New Zealand has undergone enormous transformation since the free market economics of Prime Minister David Lange (i.e. Rogernomics) instituted a controversial privatization program to unleash the country from its highly regulated structure. In addition to financial deregulation, state owned assets in utilities, telecommunications, mining, forestry, and many other sectors were sold to private investors. Support for these changes was fueled by "economic rationalism" which fostered the notion that reasoned economic analysis would always lead to support for free-market policies (Quiggin, 1998). Such changes have altered New Zealand society and in particular its market economy. Prior to these radical reforms, New Zealand was one of the most controlled and socialistic countries in the OECD (McTigue, 1998). Today, New Zealand rates as one of the most open and free economies in the world according to the Cato Institute and Heritage Foundation (McTigue, 1998).

Strong support continues today for the free market philosophy in New Zealand (Brittenden, 2000). Some analysts suggest that the radical reforms have contributed to significant economic development in New Zealand (Cherie, 1997). In particular, the Commerce Act of 1986 defined in law that competition was to be the general principle governing economic activity, which removed institutional obstacles to government action. This new economic landscape has ushered in a true market oriented society. In this new era, modern marketing methods have taken firm root in the business culture.

As deregulatory economic policies gave the private sector more discretion in business decisions, the likelihood of the abuse of power has increased. Some groups in New Zealand have questioned the social and economic consequences of a less regulated economy. Even former Prime Minister Lange said that he now regrets many of the reforms he introduced in the name of the free market (Field, 1996). Quiggin (1998) charges that the free-market reforms have resulted in increasing inequality and generally poor economic outcomes while others suggest that the free market model does not appear to have

European Journal of Marketing, Vol 37, No. 3/4 (2003): pg. 385-406. DOI. This article is @ Emerald and permission has been granted for this version to appear in e-Publications@Marquette. Emerald does not grant permission for this article to be further copied/distributed or hosted elsewhere without the express permission from Emerald. 
produced the results expected (Cameron et al., 1999; Ivey, 1997). A Research Gallup poll found that nearly two-thirds of New Zealanders believe that free market principles have gone too far (Edlin, 1996). Concern has been registered about the adequacy of the market to respond fairly and equitably to the vast range of consumer needs. In fact, the rationale for launching the Fair Trading Act (1987) was to give the consumer and business greater redress in the event of deceptive advertising. Provisions of the Act controlled for consumer related issues such as product puffery, nondisclosure, and comparative advertising among others. Some evidence suggests that the frequency and severity of deceptive advertising has diminished since this Act was passed (Lysonski and Duffy, 1992).

In the midst of this change, marketing managers in New Zealand are keen to understand how they might have to alter their marketing orientation in light of potential consumer dissatisfaction with marketing practices. Critics of privatization, for example, fear that large corporations could manipulate prices and use monopoly power to wield unfair control. Even the New Zealand Minister of Consumer Affairs, recently announced that consumer credit policy and legislation was not adequate to protect consumers from unfairness and difficulties (Chartered Accountants Journal of New Zealand, 1999).

One way to grasp the attitudes that consumers may have regarding marketing practices by business is to use the framework established by others to measure attitudes toward marketing and consumerism (e.g. Barksdale and Darden 1972). Although there is no generally accepted operational definition of consumerism (Kangun et al., 1975; Swagler, 1994), consumerism may be defined as "a social movement seeking to augment the rights and powers of buyers in relation to sellers" (Kotler, 1972). In practice, attitudes toward marketing and consumerism have been measured by examining the perceptions of consumers to marketing activities such as pricing, advertising and product quality, among others. A few studies have used the expression of "consumer sentiment" to apply to attitudes toward marketing and consumerism issues (cf Lysonski and Zotos, 1989; Gaski and Etzel, 1986); the two sets of terms fundamentally look at the same set of issues regarding consumer perceptions of the marketplace.

Consumer attitudes are an important and integral part of the marketing environment that managers need to scan to understand potential forces that could curtail marketing activities. Failure to

European Journal of Marketing, Vol 37, No. 3/4 (2003): pg. 385-406. DOI. This article is @ Emerald and permission has been granted for this version to appear in e-Publications@Marquette. Emerald does not grant permission for this article to be further copied/distributed or hosted elsewhere without the express permission from Emerald. 
monitor the environment or misdiagnosis of environmental trends can lead to serious problems for marketers (Kotler, 1972; Nicouland, 1987). One way to gauge consumers' attitudes toward marketing is to examine their perceptions towards a wide range of marketing mix activities and issues pertaining to consumerism. Proactive marketing managers are attentive to consumer problems before such problems reach crisis levels. In contrast, reactive managers wait until these problems reach a critical stage before they commit to altering their practices. Historically, some countries have found that government intervention may result if consumer dissatisfaction reaches a critical level (Harland, 1987; Ryans et al., 1985). If consumers are found to have negative or skeptical attitudes toward marketing activities, it is crucial that marketing managers determine the source of this negativity and its threat to future business actions.

The goal of this paper is to examine if consumer attitudes toward marketing and consumerism have changed in New Zealand over the last 15 years since free market economics were introduced and to assess whether these changes represent a threat to marketers. How consumers rated marketing activities in 1986 is compared to how they rate them in 2001. Specifically, we investigate perceptions of marketing activities regarding product quality, advertising, pricing, government regulations, manufacturers' consumer orientation, consumer problems and responsibilities, and attitudes towards consumerism. We anticipate that consumerism and marketing issues will be of lower concern in 2001 relative to 1986 given the extensive consumer legislation that has been enacted to protect consumers. It is also likely that consumers will recognize that firms are more customeroriented in 2001 given the widespread diffusion of the marketing concept among New Zealand businesses.

Many studies have been conducted to understand attitudes toward marketing and consumerism in other parts of the world. Yet, no recent study has examined if consumers in New Zealand have become more critical of the marketing practices and consumerist issues in light of this new business era. No study has taken a longitudinal perspective to determine if consumer perceptions have also gone through a metamorphosis. This study provides insight for marketing managers in other countries into how consumers' attitudes may change when market reforms are introduced.

The first part of this paper examines the published empirical studies on consumer attitudes toward marketing and consumerism and

European Journal of Marketing, Vol 37, No. 3/4 (2003): pg. 385-406. DOI. This article is @ Emerald and permission has been granted for this version to appear in e-Publications@Marquette. Emerald does not grant permission for this article to be further copied/distributed or hosted elsewhere without the express permission from Emerald. 
the degree to which consumers have expressed dissatisfaction with marketing activities. The theory of the consumerism life cycle as it relates to New Zealand's evolution is also examined. The second section discusses the methodology used to measure consumer perceptions. After the empirical results are presented, conclusions and implications are discussed.

\section{Background literature}

\section{The concept of consumerism}

The consumer movement was given its spark in the USA with President Kennedy's 1962 call for a "Bill of Consumer Rights" and with the appointment in 1964 of a special assistant to the President for Consumer Affairs (Lampman, 1988). Shortly thereafter, business practitioners and academicians began investigating the degree to which people were satisfied or dissatisfied with marketing practices. Under the rubric "consumerism", these researchers tried to identify the factors that most disturb consumers about marketing.

Use of the word "consumerism" has become commonplace in contemporary lexicon, yet it has been conceptualized in multiple ways (Buskirk and Rothe, 1979; Swagler, 1994). As noted above, Kotler (2000, p. 152) views consumerism as an "organized movement of citizens and government to strengthen the rights and powers of buyers in relation to sellers". McIllhenny (1990) identifies consumerism as a citizens' movement with widespread demands on suppliers of goods and services with social, ecological and political implications, while Maynes (1989) suggests that it represents the voice of consumer discontent and subsequent corrective actions. Earlier, Cravens and Hills (1973, p. 164) defined consumerism in operational terms as "a multitude of group actions concerned with such issues as consumer protection laws, the availability of product and price information, fraudulent and deceptive business practices and product safety". In essence, consumerism deals with consumer issues about a range of marketing related issues.

Because marketing is the most visible managerial function, marketing strategies and practices are viewed as reflecting the ethics or mentality of marketers. Consumerists argue that excessive marketing in terms of product differentiation and segmentation in mass consumption societies has created anxiety for consumers (Straver, 1977). Some critics argue that product differentiation is created in part to permit more segmentation of the market. Such 
differentiation is based on minor differences among brands or product lines yet price points are developed to signal large differences in quality. Consumers then assume larger quality/price differences than what objectively exists.

Consumerism issues ostensibly relate to elements of the marketing mix. For example, product policy is attacked because of problems dealing with planned obsolescence, product proliferation, safety, and labeling. Pricing policies may be criticized during periods of increasing inflation and economic crisis. Distribution policy may be attacked due to aggressive in-store merchandising techniques and lack of quality information to evaluate price/quality relationships among similar brands. Lastly, advertising strategies may be criticized because of the psychological positioning used to differentiate products, puffery, deception and the emphasis on materialism to achieve the "good life". In this paper, the use of the term consumerism is used in a broad sense with respect to business activities that impact consumers, particularly marketing activities.

In the USA, Jones and Gardner (1976) attributed the causes of consumer discontent to two reasons: first, higher expectations of a better lifestyle resulting from increasing incomes and sociological changes, and second negligence by business and government to protect consumers. Andreasen and Best (1977) documented consumer discontent arising from marketers' incompetence or reluctance to resolve complaints; the government was also blamed for the rise of consumer discontent since it was viewed as being more pro-business and not defending the interests of consumers effectively. Greyser and Diamond (1974) found that consumers were not adequately protected since laws were founded on the principle of caveat emptor. Moreover, Hustad and Pessmier (1973) found a range of marketing practices that contributed to this discontent.

Concern with consumerism and marketing issues has not been confined only to first world nations. Onah (1979) extended the idea to third-world countries by noting that it applied to efforts by consumers, government, or independent institutions to protect consumers from unscrupulous business activities driven by the profit motive. Kaynak (1982) noted that consumerism and policies against some marketing practices in developing countries expressed itself more in government legislation and enforcement vis-a-vis organized public activities. Perhaps, it is for this reason that most of the research on consumerism and marketing activities has examined first world countries where the

European Journal of Marketing, Vol 37, No. 3/4 (2003): pg. 385-406. DOI. This article is @ Emerald and permission has been granted for this version to appear in e-Publications@Marquette. Emerald does not grant permission for this article to be further copied/distributed or hosted elsewhere without the express permission from Emerald. 
NOT THE PUBLISHED VERSION; this is the author's final, peer-reviewed manuscript. The published version may be accessed by following the link in the citation at the bottom of the page.

market economies are advanced and tend to be freer of government interference.

\section{Empirical evidence on consumers' attitudes}

Over the past 20 years, several studies have sought to quantify the attitudes consumers hold toward marketing and consumerism issues. Many of these studies have been conducted in diverse national and cross-national settings. They showed a high level of consumer discontent with various aspects related to marketing and consumerism; buyer dissatisfaction on a range of issues related to marketing was also found to be widespread among countries. The initial studies looked at the USA such as the one by Barksdale and Darden (1972) which found that 70 percent of respondents in the USA believed that most manufacturers were not satisfactorily handling consumer complaints. Such complaints were associated with the quality of products, their reliability and safety aspects and were felt to be endemic to the marketing system rather than being just a failure of poorly designed corporate policy. Hence, it was believed that firms were marketing products that could potentially cause harm to the users. More recently, Roberts and Manolis (2000) compared consumerism and advertising attitudes of those born from 1946 to 1964 to those born from 1965 to 1974 in the USA. They found that there were generational differences in that the later cohort were more favorably disposed towards marketing and advertising, considered marketing to be more beneficial and marketers to be more socially responsible than did the earlier cohort.

As research progressed on consumerism, the focus began to shift to cross cultural comparisons of the USA with other counties. Such studies found common patterns of concern about marketing and consumerism issues among respondents in the USA, Venezuela and Norway (Arndt et al., 1980) as well as in England (French et al., 1982) and in other countries (Barksdale et al., 1982). Common problems for consumers were high prices, lack of product quality, lack of adequate repair and maintenance services, deceptive advertising, and inadequate handling of complaints. Several cross- cultural studies also found mixed views about consumer attitudes regarding marketing and consumerism between the USA and other countries. For example in a comparative study contrasting Sweden to the USA on marketing practices, Klein (1982) found that Swedish consumers were more satisfied. Wee and Chan (1989), also found that consumers in Hong Kong were more favorable in their attitudes towards marketing than

European Journal of Marketing, Vol 37, No. 3/4 (2003): pg. 385-406. DOI. This article is @ Emerald and permission has been granted for this version to appear in e-Publications@Marquette. Emerald does not grant permission for this article to be further copied/distributed or hosted elsewhere without the express permission from Emerald. 
those in the USA due in part to better marketing practices in Hong Kong.

The most recent focus has looked at cross-cultural investigations without including the USA for comparisons. Darley and Johnson (1993), for instance, studied marketing and consumerism issues in multiple countries: Singapore, India, Nigeria, and Kenya. They found differences among the countries but some degree of discontent appeared in all of them. Consumers in Turkey also had negative views about these issues (Uray and Menguc, 1996) while a study by Varadarajan et al. (1990) on consumers in India found discontent with marketing practices and support for greater government regulation. Lastly, Bhuian et al. (2001) found that in Saudi Arabia, young adults who had a business education background were more favorably disposed towards marketing and consumerism issues than those who had a non- business background. Irrespective of their educational backgrounds, all young adults in Saudi Arabia had positive perceptions toward consumer-related government regulations and price controls.

Likewise, Chan et al. (1990) found that Australian consumers were unfavorable in their attitudes toward marketing except for retailing, while those in Hong Kong were more favorable. They suggested that because Australians live in a more individualistic society, they are more apt to complain than Chinese in Hong Kong who live in a society that encourages internal harmony and not complaining. In sum, the preponderance of the historical studies point to negative opinions about marketing and consumerism issues in developed and developing countries while some studies find that consumers do express satisfaction with certain elements of the marketing system.

Two studies have looked at attitudes on marketing and consumerism in New Zealand, but both are seriously dated. Barker (1987) found that New Zealanders lacked confidence in business regarding its ability to meet consumers' expectations; product quality, deceptive advertising and high prices were the main areas of concern and were expressed across demographic and socioeconomic strata. Barker (1987) warned that unless business pays more attention to the way it deals with consumerism and marketing issues, more government regulation was likely. Lysonski and Zotos (1989) examined consumer perceptions in New Zealand, England, USA, and Greece. They found that respondents in the four countries were not

European Journal of Marketing, Vol 37, No. 3/4 (2003): pg. 385-406. DOI. This article is @ Emerald and permission has been granted for this version to appear in e-Publications@Marquette. Emerald does not grant permission for this article to be further copied/distributed or hosted elsewhere without the express permission from Emerald. 
critical in their beliefs about issues product quality issues. New Zealanders were the most negative about advertising, as ads were seen as unreliable sources of information, presenting unbelievable and false pictures of products.

\section{Consumerism life cycle and its relevance to New Zealand}

Little discussion has been given to the evolution of consumerism issues in the literature in the last eight years. In one exception, Rhee and Lee (1996) examined consumer activism in Korea between 1910 and 1995 and how it progressed from an anti-colonial social movement into one that targets consumers' interests at the individual and societal levels. These authors suggest that a country's political environment and the level of economic development dictate consumer activism and the focus on consumer problems. Hence, it is likely that interest in consumerism and marketing activities evolves in a country in accordance with the macroeconomic development of an economy (Bloom and Greyser, 1981; Gaedeke and Udo-Aka, 1974). This evolution can be seen in terms of the amount of consumer information that is available in the marketplace, the degree to which legislation is enacted to protect consumers, the emergence of government institutions or actions that seek to protect consumers and the level of public financing of consumer education programs. Another important indicator of the evolution of consumerism in a country relates to the mentality of consumers and their awareness and sensitivity towards consumer issues.

Kaufman and Channon (1973), Kaynak (1985) and Straver (1977) suggest that countries may follow a consumerism life cycle. This life cycle posits that consumerism is much like any social movement and, therefore, subject to a life cycle pattern of development. These authors suggest that the life cycle of consumerism can be classified into four stages or phases:

(1) crusading;

(2) popular movement;

(3) organizational/managerial; and

(4) bureaucratic (Barker, 1987; Straver, 1977).

Kaynak (1985) and Straver (1977) also suggest that individual nations can be classified in terms of the consumerism life cycle stage

European Journal of Marketing, Vol 37, No. 3/4 (2003): pg. 385-406. DOI. This article is @ Emerald and permission has been granted for this version to appear in e-Publications@Marquette. Emerald does not grant permission for this article to be further copied/distributed or hosted elsewhere without the express permission from Emerald. 
they are experiencing. It is likely that the attitudes that consumers have towards marketing consumerism issues relate to the stage in which consumerism has developed in a country.

In developing a general theory on consumerism, Hendon (1975) postulates that seven conditions affect the timing, intensity and likelihood of consumerism. Each of these conditions is listed below, as is the condition's likely impact on consumerism in New Zealand. As the conditions increase, Hendon (1975) proposes that consumerism is more likely:

(1) Level of inflation. New Zealand experienced high levels of inflation in the mid-1980s but since 1990 there has been moderate inflation, which has not created consumer protests.

(2) Proximity of sufficient people who are willing to act collectively. New Zealand has not seen major concerted efforts to control business.

(3) Presence of restrictive environmental movements such as restrictive political and legal systems and class conflict. New Zealand has not seen any concerted movements since 1985.

(4) Pace of economic development. New Zealand has seen significant changes in economic development given the degree of privatization in the economy. The government no longer controls major industries as it did prior to 1985 . Unemployment and poverty have increased.

(5) Complexity or sophistication of consumer issues (when the issues are basic, there is more likely to be stronger consumer interest). There is now concern in New Zealand about the impact of some of free market reforms on the welfare of society.

(6) Class distinctions (as lower income classes become more affluent, less discontent is likely). In New Zealand, lower income classes are seeing much more hardship compared to the pre-free market era. The social welfare "safety net" is no longer as secure as it was prior to 1985.

(7) Over sophisticated economy whereby problems of consumption outweigh the problems of production. In New Zealand, consumption problems have appeared due to growing inequality of incomes. Unemployment has increased and the distribution of income has become more skewed. A large middle class has been able to enjoy cheaper goods given the end of import restrictions. 
Moreover, transnational corporations continue to penetrate New Zealand especially in the media and in retail.

Given the changes noted above, it is likely that consumerism and marketing issues have evolved significantly since the mid-1980s when free market policies began. It is likely that New Zealand may have gone from an organizational/managerial stage (phase 3) to phase 4 where government institutions and policies emerged to protect the interests of consumers. We, therefore, would expect New Zealand consumers to be as conscious of consumerism and marketing issues in more current years yet less critical since government mechanism may have mitigated the abuses that heretofore were more common. Thorelli (1990) argues that more developed economies are likely to have higher levels of consumer dissatisfaction with consumer issues given the higher levels of education and higher consumption standards. Similarly, Kaynak and Wilkstrom (1985) observed that higher incomes and education give rise to higher expectations, which are more likely to produce greater dissatisfaction and cynicism among consumers. Hendon (1975) also argues that as consumers become more affluent, their needs become more complex and therefore more difficult to satisfy, resulting in a greater likelihood of dissatisfaction. Finally, Thorelli (1981) posits that there is a high association between consumer aspiration levels and the economic development of a country, which has been supported by a study by Thorelli and Sentell (1982) showing that consumers in less developed countries have low levels of aspirations reflecting the macroeconomic conditions.

Evidence that New Zealand is in the last stage of the consumer life cycle may be seen by the plethora of legislation aimed at protecting the consumer since the free market era began. Among the best known of this legislation are the Fair Trading Act (1987) (as discussed above), The Health and Safety in Employment Act 1992, the Resources Management Act 1991, and the new Companies Act and the Consumer Guarantees Acts of 1993. The Consumer Guarantees Act of 1993 represents New Zealand's effort at the modernization of consumer sales law (Ahdar, 2000). Furthermore, in early 2000 the New Zealand Food Authority released a draft code that will require food manufacturers to label all products with the percentage of main ingredients and put nutritional labels on all packaged food. Recently, New Zealand health ministers voted to adopt one of the strictest mandatory food labeling laws in the world (Ban, 2001). Presently there is discussion to give consumers more protection in their use of credit

European Journal of Marketing, Vol 37, No. 3/4 (2003): pg. 385-406. DOI. This article is @ Emerald and permission has been granted for this version to appear in e-Publications@Marquette. Emerald does not grant permission for this article to be further copied/distributed or hosted elsewhere without the express permission from Emerald. 
NOT THE PUBLISHED VERSION; this is the author's final, peer-reviewed manuscript. The published version may be accessed by following the link in the citation at the bottom of the page.

(Hattaway 2000). These changes suggest that New Zealand is clearly evolving in terms of consumer issues.

\section{Research methodology}

The research instrument to measure consumer attitudes toward marketing and consumerism has been used in several studies and represents the most frequently used approach to measure the construct (Barksdale and Darden, 1972; Barksdale and Perreault, 1980). Gaski and Etzel (1986) used many aspects of the instrument to develop their approach called "consumer sentiment" to measure consumer attitudes toward marketing and consumerism. Likert scales were used such that each respondent registered his/her level of agreement for 39 items on a balanced rating scale ranging from strongly agree (1) to strongly disagree (5). The 39 items related to seven areas of consumer perceptions. As identified by Barksdale and Darden (1972), these seven areas are:

(1) product quality;

(2) advertising;

(3) pricing issues;

(4) government regulation;

(5) customer orientation;

(6) consumer problems and responsibilities; and

(7) consumerism.

We believe that each of these areas continues to be important in determining consumers' attitudes towards consumerism issues. However, it is likely that customer orientation is a less important issue these days given that many firms have now embraced the marketing concept, which is in fact a customer orientation.

The questionnaire was administered in New Zealand. A sample of 149 subjects responded to the survey in 1986 and another sample of 144 subjects responded to the same survey in 2001. Nearly equal proportions of men and women were in each of the samples. The mean age of each sample group was approximately 22 .

In both the 1986 and the 2001 samples, the sampling frame limited respondents to the young adult population with a university education background. Consequently, the two samples are similar in a

European Journal of Marketing, Vol 37, No. 3/4 (2003): pg. 385-406. DOI. This article is @ Emerald and permission has been granted for this version to appear in e-Publications@Marquette. Emerald does not grant permission for this article to be further copied/distributed or hosted elsewhere without the express permission from Emerald. 
matched sample sense, making it possible to measure changes in consumer attitudes in the last 15 years. Even though young adults represent a very specific consumer segment, these respondents represent an important segment with substantial discretionary income. They also reflect the attitudes of the new generation - attitudes that have been conditioned by various reference groups such as parents, schools and friends. Further, for certain products, young adults represent a group that is the target of most advertisers, especially for products such as soft drinks, fast foods, or fashion items. While young adults have been found to have indifferent to negative attitudes toward advertising, their responses are typically consistent with those of the general population (Zanot, 1984). Moreover, Barker (1987) found no differences demographically for consumerism and marketing issues when he investigated New Zealand. Parenthetically, it is possible that this younger segment of consumers might be less dissatisfied than the general population given that they have less experience as consumers vis-à-vis older, more experienced one who remember the highly regulated New Zealand economy.

\section{Results}

Employing multivariate analysis of variance, we first compared the overall vector of mean values consisting of those 39 statements representing consumer attitudes towards marketing and consumerism for the 2001 sample and the 1986 sample. Results are as follows: Wilk's $\Lambda=0.012, F=321.075, p=0.00$, and effect size $(\eta 2)=0.960$. This statistic demonstrates that overall, the mean responses to the consumer perceptions scales are significantly different for the two samples. To understand where the mean values for the two samples differed, univariate analyses were performed for each statement. Moreover, examining each question independently gives the reader a more penetrating view into the mindsets of New Zealanders attitudes towards marketing and consumerism. Results of these univariate analyses are presented in Tables I-VII.

Parenthetically, it should be noted that a factor analysis of the items did not show a factor structure along the seven dimensions identified by Barksdale and Darden (1972). Hence, the dimensionality limitations of the scale do not allow computation of composite measures of each of the seven dimensions. For ease of understanding the results, the 39 statements are categorized into seven areas corresponding to the main concerns of consumers and according to the conventions used in preceding studies by other researchers

European Journal of Marketing, Vol 37, No. 3/4 (2003): pg. 385-406. DOI. This article is @ Emerald and permission has been granted for this version to appear in e-Publications@Marquette. Emerald does not grant permission for this article to be further copied/distributed or hosted elsewhere without the express permission from Emerald. 
investigating consumerism and marketing issues. For comparison purposes, each table presents mean values for the two samples along with $\mathrm{p}$-values for the mean difference tests.

\section{Product quality}

Table I shows mean attitude scores toward product quality. There are two noteworthy findings from this table. Both samples tend to agree that manufacturers make an effort to design products that fit consumer needs (statement 1 ) and that the quality of most products has improved (statement 2). The degree of this agreement, however, is stronger for the 2001 sample than for the 1986 sample.

Parenthetically, it should be noted that statement 2 is negatively worded, but both samples disagreed with this statement (mean $>3$ ). Hence, we can conclude that respondents in 2001 have significantly more favorable perceptions about product quality as compared to those for the 1986 sample. It is likely that government measures to protect consumers more effectively have had some impact on product quality in the last 15 years.

[Table I]

[Table II ]

[Table III]

\section{Advertising}

Both samples exhibited generally negative attitudes toward advertising (see Table II). The 2001 sample, however, has significantly less negative perceptions as evident from the $\mathrm{p}$-values. Both samples tend to disagree that advertisements are reliable sources of information about product quality and performance (statement 1), advertised products are more dependable than the unadvertised ones (statement 2), company sponsored ads present a true picture of the products advertised (statement 3 ), and the product advertising is believable (statement 4 ). The only positive perception for either sample is that the manufacturer sponsored games and contests aimed to increase product purchase are not considered dishonest (statement 5). Parenthetically, it should be noted that statement 5 is negatively 
worded, but the two sample groups have disagreed with it (mean of 3.72). Hence, these results show that advertising issues remain a concern in New Zealand, but this concern has diminished over time.

[Table IV]

[Table V]

\section{Price and price controls}

As shown in Table III, New Zealanders continue to be skeptical about the motives of managers in serving customers. The perception that high prices are caused by wholesalers and retailers taking excessive profits is significantly stronger now than it was in 1986. Respondents in 2001 also feel significantly more strongly that government price control keeps prices at a reasonable level.

It must be kept in mind that price controls were common in the prederegulation era and virtually non-existent in the present era. Although both samples feel manufacturers are more interested in making profits than serving customers (statement 5), they recognize that competition facilitates fair pricing for products (statement 4). Yet, neither of these attitudes differ significantly for the two groups. Finally, current respondents indicate significantly greater agreement that products are priced fairly (mean $=2: 85$ ) as compared to respondents from 1986 (mean 3.13) (statement 2).

\section{[Table VI]}

\section{Government regulation}

As presented in Table IV, none of the mean attitude scores for any of the items related to government regulation differed significantly between the 1986 and 2001 samples (p.0.05). However, in general both groups felt positively toward government regulation. For example, the statement that the government should test competing brands of products and make the test results available to consumers 
NOT THE PUBLISHED VERSION; this is the author's final, peer-reviewed manuscript. The published version may be accessed by following the link in the citation at the bottom of the page.

had mean scores of 2.57 or less (statement 1 ), and the statement that government should set minimum standards of quality for all products sold to consumers had mean scores of 2.24 or less for both samples (statement 2).

However, both groups agree that if possible, self-regulation by business is preferable to government control (mean of 2.69 or less) (statement 5). In the absence of such a regulation, a governmental department of consumer concern is considered important for protecting and promoting consumer interests (statement 4). Parenthetically, it should be noted that statement 4 is negatively worded, but the two sample groups have disagreed with it (mean of about 3.71). These results signal that consumers view government as an important force in consumerism and marketing issues. It is likely that consumers will call on government to address consumer problems if business does not monitor itself.

[Table VII]

\section{Customer orientation}

There was one significant difference between the 1986 sample and the 2001 sample with respect to the area of customer orientation. As shown in Table V, 1986 respondents did not feel that manufacturers operate on the philosophy that that the consumer is always right (mean $=3.42$ ) (statement 1$)$, while the 2001 respondents indicated significantly greater agreement with the statement (mean $=2.70, \mathrm{p}<$ $0.05)$. Such responses suggest that respondents feel that firms have become more customer-focused.

\section{Consumer problems and responsibilities}

Table VI presents the mean values for attitudes related to consumer problems and responsibilities. The results clearly indicate that current respondents exhibit more concern for the environment than the 1986 sample. In a relative sense, the 2001 sample is significantly more likely to agree that consumers are willing to pay higher prices for environmentally friendly products (statement 3 ). In addition, the 2001 sample indicates that concern for the environment influences product choice (statement 6) to a greater extent than it did for the earlier sample.

European Journal of Marketing, Vol 37, No. 3/4 (2003): pg. 385-406. DOI. This article is @ Emerald and permission has been granted for this version to appear in e-Publications@Marquette. Emerald does not grant permission for this article to be further copied/distributed or hosted elsewhere without the express permission from Emerald. 
In terms of other statistically significant results, current respondents agree more than individuals from the 1986 sample that consumers take advantage of manufacturers and dealers by making unjustified claims (statement 7). This finding is not altogether surprising, considering that the 2001 sample (and the 1986 sample to some extent) perceives that both manufacturers and dealers are more profit-oriented and less customer-oriented (see statements 1 and 5 in Table III). These results suggest that consumers experience greater complexity in their consumer problems, which may illustrate that New Zealand is more advanced in its consumerism life cycle.

\section{Consumerism}

Table VII shows mean responses to statements about consumerism attitudes. Importantly, both 1986 and 2001 samples feel that exploitation of consumers by business firms deserves more attention than it receives (statement 4). They also feel that consumerism is an important issue today (statement 6) and in the future (statement 7). This is because the mean responses to all of these statements are below 3 for both the samples. However, for statements 4 and 7, the significantly lower mean scores for the 1986 sample $(p<0.05)$ imply that the intensity of these feelings is stronger for this sample than for the 2001 sample.

\section{Discussion and implications}

One can infer from the results of this study that consumerism and marketing issues in New Zealand are less problematic than 15 years ago. Undoubtedly, while consumerism and marketing issues will always be important to New Zealanders, New Zealand has become more advanced in its legislation and regulations to protect consumers as witnessed by the pro-consumer legislation discussed earlier. Hence, consumer issues are better addressed now by a formal government framework compared to the absence of this framework prior to the late 1980s. It is likely that government efforts to establish laws and regulations to protect consumer interests have succeeded, as deregulation and heightened competition appear to be good for consumers. Hence, even though the results show that consumerism and marketing issues are less pressing now, it is probably because New Zealand has become more sophisticated in dealing with the issues.

In 2001, consumers have relatively more favorable attitudes toward product quality, and in comparison to 15 years ago, consumers

European Journal of Marketing, Vol 37, No. 3/4 (2003): pg. 385-406. DOI. This article is @ Emerald and permission has been granted for this version to appear in e-Publications@Marquette. Emerald does not grant permission for this article to be further copied/distributed or hosted elsewhere without the express permission from Emerald. 
today think that manufacturers are more customer- focused in that they make products that fit consumer needs. Manufacturers are thought to be concerned about consumer complaints and make a sincere effort to handle consumer complaints as well. These results suggest that New Zealand may have moved into a new era of consumerism in terms of its life cycle. Alternatively, it is also possible that the general levels of expectations of corporate activity have changed. While it is not completely possible to say unequivocally that a new era of consumerism and concern for marketing issues is now under way in New Zealand, it can be argued that the significant proconsumer legislation enacted since the mid-1980s has altered the corporate landscape. With consumer interests better represented than in the past, there is less of an urgent need to address critical issues. Consequently, the stage does not seem to be set for consumer action at this time.

Consumers recognize that companies are in business to make money, however. Such recognition may explain why the 2001 consumers share similar negative attitudes toward advertising with the 1986 sample, even though the degree of such negativism is significantly smaller today. For example, respondents did not view manufacturers' advertisements as providing reliable information about quality and performance or that ads present a true picture of products. New Zealand firms have a timely opportunity to use these results to understand consumer grievances. Further analysis may help identify opportunities to make advertising more informative and to identify operational and tactical deficiencies.

Also concerning manufacturers' profits, respondents continue to agree that companies are more profit oriented than customer oriented. In addition, there is a stronger perception today that high prices for consumer goods can be attributed to excessive profit taking by members in the distribution chain such as wholesalers and retailers. What is the solution? One option is to encourage competition to control prices. This perception is shared by both the samples.

With respect to the government's role in protecting consumer interests, both samples agree that government can establish minimum standards for product quality as well as perform independent tests of competing brands and publish the results. They also agree that there is a need for a governmental department of consumer protection. However, respondents do not feel that government price control is the most effective way of keeping prices at a reasonable level. Given the 
role that government has played in the USA and Sweden to control marketing practices, it is possible that the New Zealand government may impose more controls on the marketplace. Such actions typically result if government officials believe it is the government's role to be involved with that particular issue or if the government feels it can assist in solving the problem. As a result, managers need to be proactive and use self-policing systems to preclude government from excessive involvement. If businesses do not respond to consumer needs responsibly, they must expect that government institutions will fulfill this role. Clearly, it is very unclear if government policy is the primary cause of changes in the economic system or if new government policies will improve any perceived problems.

It is important to remember that consumers use a variety of information when making purchasing decisions. For example, a recent study on New Zealand consumers found that one in five reported rewarding or punishing companies in the previous year based on their perceived social performance (Tapsell 2000). Consumers today also exhibit more concern for the environment than they did 15 years ago. This concern is more likely to affect product choices today than in the past.

Overall, the results offer some insight applicable to other economies in the world. Despite some protests in New Zealand that deregulation has gone too far, consumers' attitudes have become more favorable about the marketplace as expressed through their attitudes about marketing activities and consumerism. Deregulation is said to unleash an entrepreneurial spirit or force of "creative destruction". Businesses can then strive to succeed without excessive or oppressive government interference; such interference may tend to create economic inefficiencies and power in the hands of a few firms. For economies in highly-regulated business environments, consumers are likely to be receptive to economic changes and reforms once they experience the concomitant benefits resulting from deregulation. More competition and a more level playing field are likely to give consumers greater choice. Subsequently, greater choice is likely to enhance consumer welfare leading to greater satisfaction with the economic and marketing system. Hence, attitudes towards marketing and consumerism issues are likely to be less problematic when an economy is allowed to operate more freely and government creates rules that encourage fair play and equal access to the market system for all businesses.

European Journal of Marketing, Vol 37, No. 3/4 (2003): pg. 385-406. DOI. This article is @ Emerald and permission has been granted for this version to appear in e-Publications@Marquette. Emerald does not grant permission for this article to be further copied/distributed or hosted elsewhere without the express permission from Emerald. 
In sum, the results from this study indicate that in New Zealand there has been significant change in consumer perceptions over the last fifteen years (2001 vs 1986), and in contrast to the results that Barker (1987) found for New Zealand, New Zealand managers are exhibiting more responsiveness to consumer issues. Nonetheless, marketers must continue to remain vigilant in identifying and addressing any significant consumer complaints that may arise. Should this awareness continue to occur and should New Zealand continue to prosper in its deregulatory environment, it is the consumers who ultimately benefit.

\section{References}

Ahdar, R. (2000), "Consumer guarantees in the New Zealand Court of Appeals", Australian Business Law Review, Vol. 28 No. 4, pp. 313-6.

Andreasen, A. and Best, A. (1977), "Consumers' complaints: does business respond?" Harvard Business Review, Vol. 55, July/August, pp. 319-24.

Arndt, J., Barksdale, H. and Perrreault, W. (1980), "Comparative study of attitudes toward marketing, consumerism, and Government regulation: the United States versus Norway, and Venezuela", in Day, R. and Hunt, H.K. (Eds), New Findings in Consumer Satisfaction and Complaining, Indiana University, Bloomington, IN, pp. 66-72.

Ban, E. (2001),"AFGC fails to stop new labeling laws", Retail World, Vol. 54 No. 3, p. 8.

Barker, T.A. (1987), "Consumerism in New Zealand", International Marketing Review, Vol. 3 No. 3, pp. 63-75.

Barksdale, H.C. and Darden, W.R. (1972), "Consumer attitudes toward marketing and consumerism", Journal of Marketing, Vol. 36, pp. 2835.

Barksdale, H.C. and Perreault, W.D. (1980), "Can consumers be satisfied", MSU Business Topics, Vol. 28, pp. 19-30.

Barksdale, H.C., Perreault, W.D., Arndt, J., Barnhill, J., French, W., Halliday, M. and Zif, J. (1982),"A cross national survey of consumer attitudes towards marketing practices, consumerism, and Government regulations", Columbia Journal of World Business, Vol. 17, pp. 71-86.

Bhuian, S.N., Abdul-Muhmin, A.G. and Kim, D. (2001), "Business education and its influence on attitudes to business, consumerism, and Government in Saudi Arabia", Journal of Education for Business, Vol. 76 No. 4, pp. 226-30. Bloom, P. and Greyser, S.A. (1981), "The maturing of consumerism", Harvard Business Review, Vol. 59, November/December, pp. 130-9.

European Journal of Marketing, Vol 37, No. 3/4 (2003): pg. 385-406. DOI. This article is @ Emerald and permission has been granted for this version to appear in e-Publications@Marquette. Emerald does not grant permission for this article to be further copied/distributed or hosted elsewhere without the express permission from Emerald. 
NOT THE PUBLISHED VERSION; this is the author's final, peer-reviewed manuscript. The published version may be

accessed by following the link in the citation at the bottom of the page.

Brittenden, W. (2000), "The friendly free market", New Zealand Listener, Vol. 172 No. 3112, pp. 32-5.

Buskirk, R.H. and Rothe, J.T. (1979), "Consumerism: an interpretation", Journal of Marketing, Vol. 34, pp. 61-5.

Cameron, A., Massey, C. and Tweed, D. (1999), "Political possibilities for business development", Chartered Accountants Journal of New Zealand, Vol. 78 No. 10, pp. 13-17.

Chan, E., Yau, O. and Chan, R. (1990), "Consumer sentiment in Australia: a replication and crossnational comparison", European Journal of Marketing, Vol. 24 No. 10, pp. 44-59.

Chartered Accountants Journal of New Zealand (1999), "Consumer legislation targeted", Vol. 78 No. 7, p. 66.

Cherie, M. (1997), "How companies fare in a really liberated economy", Global Finance, Vol. 11 No. 1, pp. 22-6.

Cravens, D.W. and Hills, G.E. (1973), "The eternal triangle: business, government and consumers", in Murray, B.B. (Ed.), Consumerism, Goodyear, Pacific Palisades, CA, pp. 233-42.

Darley, W.K. and Johnson, D.M. (1993), "Cross-national comparison of consumer attitudes toward consumerism in four developing countries", Journal of Consumer Affairs, Vol. 27 No. 1, pp. 37-54.

Edlin, B. (1996), "The privatization war continues", Management (Auckland), Vol. 43 No. 3, p. 1.

Fair Trading Act (1987) New Zealand Government Printer, Auckland.

Field, C. (1996), "New Zealand Labor repents love affair with free market", The Ottawa Citizen, April 25, p. A11.

French, W.A., Barksdale, H.C. and Perreault, W.D. (1982), "Consumer attitudes towards marketing in England and the United States", European Journal of Marketing, Vol. 16 No. 6, pp. 20-30.

Gaedeke, R. and Udo-Aka, U. (1974), "Toward the internationalization of consumerism", California Management Review, Vol. 27, pp. 86-92.

Gaski, J. and Etzel, M. (1986), "The index of consumer sentiment toward marketing", Journal of Marketing, pp. 71-81.

Greyser, S.A. and Diamond, S.L. (1974), "Business is adapting to consumerism", Harvard Business Review, Vol. 15, September/October, pp. 38-40.

Harland, D. (1987), "The United Nations guidelines for consumer protection", Journal of Consumer Policy, Vol. 10, pp. 245-66.

European Journal of Marketing, Vol 37, No. 3/4 (2003): pg. 385-406. DOI. This article is (C) Emerald and permission has been granted for this version to appear in e-Publications@Marquette. Emerald does not grant permission for this article to be further copied/distributed or hosted elsewhere without the express permission from Emerald. 
NOT THE PUBLISHED VERSION; this is the author's final, peer-reviewed manuscript. The published version may be accessed by following the link in the citation at the bottom of the page.

Hattaway, M. (2000), "Consumer credit law changes on the horizon", Chartered Accountants Journal of New Zealand, Vol. 79 No. 5, pp. 302.

Hendon, D.W. (1975), "Towards a theory of consumerism", Business Horizons, August, pp. 16-24.

Hustad, T.P. and Pessmier, E.A. (1973), "Will the real consumer acitivitts please stand up: an examination of consumers: opinions about marketing practices", Journal of Marketing Research, pp. 319-24.

Ivey, M. (1997), "New Zealand feels winds of change", Madison Capital Times, April 26, pp. 1C-2C.

Jones, M.G. and Gardner, D.M. (1976), Consumerism: A New Force in Society, D.C. Heath, Lexington, MA.

Kangun, N., Cox, K., Higgenbotham, J. and Burton, J. (1975), "Consumerism and marketing management", Journal of Marketing, Vol. 39, pp. 3-10.

Kaynak, E. (1982), Marketing in the Third World, Praeger, New York, NY.

Kaynak, E. (1985), "Some thoughts on consumerism in developed and less developed countries", International Marketing Review, Vol. 2, pp. 1530.

Kaynak, E. and Wilkstrom, S. (1985), "Methodological framework for crossnational comparisons of consumerism issues in multiple environments", European Journal of Marketing, Vol. 19, pp. 31-47.

Kaufman, I. and Channon, D. (1973), "International consumerism: a threat or opportunity?", Industrial Marketing Management, Vol. 3, pp. 1-14.

Klein, G.D. (1982), "Development of a cross-cultural instrument to measure the attitudes of consumers and business people toward consumerism", Journal of Marketing and Public Policy, Vol. 1, pp. 123-37.

Kotler, P. (1972), "What consumerism means for marketers", Harvard Business Review, Vol. 50, May/June, pp. 48-57.

Kotler, P. (2000), Marketing Management, Prentice-Hall, New York, NY.

Lampman, R.J. (1988), "JFK's four consumer rights: a retrospective view", in Maynes, E.S. (Ed.), The Frontier of Research in the Consumer Interest, American Council of Consumer Interests, Columibia, MO, pp. 19-33.

Lysonski, S. and Duffy, M. (1992), "The New Zealand Fair Trading Act of 1986: deceptive advertising", The Journal of Consumer Affairs, Vol. 26 No. 1 , pp. 177-91.

European Journal of Marketing, Vol 37, No. 3/4 (2003): pg. 385-406. DOI. This article is @ Emerald and permission has been granted for this version to appear in e-Publications@Marquette. Emerald does not grant permission for this article to be further copied/distributed or hosted elsewhere without the express permission from Emerald. 
NOT THE PUBLISHED VERSION; this is the author's final, peer-reviewed manuscript. The published version may be accessed by following the link in the citation at the bottom of the page.

Lysonski, S. and Zotos, G. (1989), "Consumer sentiment: New Zealand versus England, USA and Greece", New Zealand Journal of Business, Vol. 27 No. 4, pp. 8-14.

McIllhenny, J.H. (1990), "The new consumerism: how will business respond", At Home with Consumers, Vol. 11 No. 5, pp. 9-10.

McTigue, M.P. (1998), "Alternative to regulation: a study of reform in New Zealand", Regulation, Vol. 21 No. 1, pp. 34-40.

Maynes, S.E. (1989), The Future of Consumerism: Guardians of the Marketplace, Twayne Publishers, Boston, MA.

Nicouland, B.M. (1987), "Consumerism and marketing management's responsibility", European Journal of Marketing, Vol. 21 No. 3, pp. 7-16.

Onah, J.O. (1979), "Consumerism in Nigeria", in Onah, J.O. (Ed.), Marketing in Nigeria: Experience in a Developing Economy, Cassell Ltd, London, pp. 126-34.

Quiggin, J. (1998), "Social democracy and market reform in Australia and New Zealand", Oxford Review of Economic Policy, Vol. 14 No. 1, pp. 76-95.

Rhee, K.-C. and Lee, J. (1996), "Review of consumer activism in Korea, 19101995: a politicaleconomic approach", Journal of Consumer Policy, Vol. 19 No. 3, pp. 365-92.

Roberts, J.A. and Manolis, C. (2000), "Baby boomers and busters: an exploratory investigation of attitudes toward marketing, advertising and consumerism", Journal of Consumer Marketing, Vol. 17 No. 6/7, pp. 481-99.

Ryans, J.K., Samiee, S. and Wills, J. (1985), "Consumerist movement and advertising regulation in the international environment: today and the future", European Journal of Marketing, Vol. 19, pp. 5-11.

Straver, W. (1977), "The international consumerist movement", European Journal of Marketing, Vol. 11 No. 2, pp. 93-117.

Swagler, R. (1994), "Evolution and application of the term consumerism: theme and variations", Journal of Consumer Affairs, Vol. 28 No. 2, pp. 347-61.

Tapsell, S. (2000), "Power to the people", New Zealand Management, Vol. 47 No. 6, pp. 32-4.

Thorelli, H.B. (1981), "Consumer policy for the Third World", Journal of Consumer Policy, Vol. 3, pp. 197-211.

European Journal of Marketing, Vol 37, No. 3/4 (2003): pg. 385-406. DOI. This article is @ Emerald and permission has been granted for this version to appear in e-Publications@Marquette. Emerald does not grant permission for this article to be further copied/distributed or hosted elsewhere without the express permission from Emerald. 
NOT THE PUBLISHED VERSION; this is the author's final, peer-reviewed manuscript. The published version may be accessed by following the link in the citation at the bottom of the page.

Thorelli, H.B. (1990), "Performance audits: the MNC through glasses of the LDC", in Thorelli, H.B. and Cavusgil, S.T. (Eds), International Marketing Strategy, Pergamon Press, Oxford, pp. 605-17.

Thorelli, H.B. and Sentell, G.D. (1982), Consumer Emancipation and Economic Development: The Case of Thailand, JAI Press, Greenwich, CT.

Uray, N. and Menguc, B. (1996), "Testing the cross-cultural generalizability of the scale of consumer attitudes toward marketing and consumerism", Journal of International Consumer Marketing, Vol. 9 No. 2, pp. 65-93.

Varadarajan, P., Rajan, P. and Thirunarayana, P. (1990), "Consumers' attitudes towards marketing practices, consumerism and government regulations: cross-national perspective", European Journal of Marketing, Vol. 24 No. 6, pp. 6-24.

Wee, C.H. and Chan, M. (1989), "Consumer sentiment towards marketing in Hong Kong", Asia Pacific International Journal of Marketing, Vol. 1 No. 1 , pp. 25-9.

Zanot, E.J. (1984), "Public attitudes toward advertising: the American experience", International Journal of Advertising, Vol. 3, pp. 3-15.

Table I. Attitudes toward product quality

1. In general, manufacturers make an effort

$$
1986 \text { sample } 2001 \text { sample } \quad p \text {-value }
$$

to design products to fit the needs of

consumers

$\begin{array}{lll}2.62 & 2.19 & 0.000\end{array}$

2. Over the past several years, the quality

of most products has not improved

3. From the consumer's point of view, Style changes are not as important as improvements in product quality

2.98

0.174

4. The wide variety of competing products and brands makes intelligent buying decisions more difficult to make $\quad 2.69$

5. For most types of products, the differences among competing brands are insignificant and unimportant

6. Manufacturers do not deliberately design products which will wear out as quickly as possible

Note: All items are measured on a five-point scale where 1 1/4 strongly agree and $51 / 4$ strongly disagree. The Table shows item mean ratings for the two samples along with $\mathrm{p}$-values associated with the mean difference tests 
NOT THE PUBLISHED VERSION; this is the author's final, peer-reviewed manuscript. The published version may be accessed by following the link in the citation at the bottom of the page.

Table II. Attitudes toward advertising

1. Manufacturers' advertisements are

$$
1986 \text { sample } 2001 \text { sample } \quad p \text {-value }
$$

Reliable sources of information about the

quality and performance of products $\quad 3.93$

$3.29 \quad 0.000$

2. Generally, advertised products are more

dependable than unadvertised ones 3.64

$\begin{array}{lll}3.64 & 3.31 & 0.004\end{array}$

3. Manufacturers' advertisements usually

present a true picture of the products

advertised

3.66

$3 \cdot 41$

0.021

4. Most product advertising is believable 3.41

3.20

0.055

5 . The games and contests that manufacturers sponsor to encourage people to buy their products are usually dishonest

3.72

$3 \cdot 72$

0.974

Note: All items are measured on a five-point scale where 1 1/4 strongly agree and $51 / 4$ strongly disagree. The Table shows item mean ratings for the two samples along with $\mathrm{p}$-values associated with the mean difference tests

Table III. Attitudes toward price and price control

1. High prices of consumer goods are

1986 sample 2001 sample $\quad p$-value caused primarily by wholesale and retail

middle-people taking excessive profits $\quad 2.99$

2.74

0.022

2. Considering the wage rates and income

Levels today, most consumer products are

priced fairly

2.85

0.011

3. Government price control is the most

Effective way of keeping the prices of

consumer products at a reasonable level 3.77

$3.12 \quad 0.000$

4. Competition ensures that consumers pay

a fair price for products $\quad 2.24$

$2.24-2.08$

0.148

5. Most manufacturers are more interested in making profits than in serving consumers

$2.32 \quad 2.49$

0.123

Note: All items are measured on a five-point scale where 1 1/4 strongly agree and $51 / 4$ strongly disagree. The Table shows item mean ratings for the two samples along with $p$-values associated with the mean difference tests

European Journal of Marketing, Vol 37, No. 3/4 (2003): pg. 385-406. DOI. This article is @ Emerald and permission has been granted for this version to appear in e-Publications@Marquette. Emerald does not grant permission for this article to be further copied/distributed or hosted elsewhere without the express permission from Emerald. 
NOT THE PUBLISHED VERSION; this is the author's final, peer-reviewed manuscript. The published version may be accessed by following the link in the citation at the bottom of the page.

Table IV. Attitudes toward Government regulation

1. The government should test competing

1986 sample 2001 sample $\quad p$-value brands of products and make results of these

tests available to consumers

$\begin{array}{lll}2.48 & 2.57 & 0.461\end{array}$

2. The government should set minimum

standards of quality for all products sold to

consumers

0.731

3. The government should exercise more

responsibility for regulating the advertising,

sales and marketing activities of

manufacturers

3.12

0.665

4. A governmental Department of Consumer

Protection is not needed to protect and

Promote the interests of consumers

$3 \cdot 72$

0.955

5. In general, self-regulation by business

itself is preferable to stricter control of

business by the government

0.080

Note: All items are measured on a five-point scale where 1 1/4 strongly agree and $51 / 4$ strongly disagree. The Table shows item mean ratings for the two samples along with $p$-values associated with the mean difference tests

\section{Table V. Attitudes toward consumer orientation}

1. Most manufacturers operate on the philosophy

1986 sample 2001 sample $\quad p$-value that the consumer is always right $\quad 3.42$

$2.70 \quad 0.000$

2. Despite what is frequently said, "Let the

Buyer beware" is the guiding philosophy of
Most manufacturers
2.91
2.86
0.614

3. Manufacturers seldom shirk their

responsibility to the consumers

3.16

0.078

4. Generally, product guarantees are backed-up

by the manufacturers who make them $\quad 2.36$

0.061

Note: All items are measured on a five-point scale where $1 \frac{1 / 4}{4}$ strongly agree and $51 / 4$ strongly disagree. The Table shows item mean ratings for the two samples along with $p$-values associated with the mean difference tests

European Journal of Marketing, Vol 37, No. 3/4 (2003): pg. 385-406. DOI. This article is @ Emerald and permission has been granted for this version to appear in e-Publications@Marquette. Emerald does not grant permission for this article to be further copied/distributed or hosted elsewhere without the express permission from Emerald. 
Table VI. Attitudes consumer problems and responsibilities

1. The problems of consumers are less serious now than in the past 1986 sample 2001 sample

$p$-value

2. The information needed to become a well informed consumer is readily available to most people

3. The average consumer is willing to pay higher prices for products that will cause less environmental pollution

0.000

4. The problems of the consumer are relatively unimportant when compared with the other questions and issues faced by the average family

5. Many of the mistakes that consumers make in buying products are the result of their own carelessness or ignorance $\quad 2.74$

6. Concern for the environment does not influence the product choices made by most consumers $\quad 2.76$ 0.003

7. Consumers often try to take advantage of manufacturers and dealers by making claims that are not justified 3.24 2.90 0.001

Note: All items are measured on a five-point scale where $1 \frac{1 / 4}{4}$ strongly agree and $51 / 4$ strongly disagree. The Table shows item mean ratings for the two samples along with $p$-values associated with the mean difference tests 
NOT THE PUBLISHED VERSION; this is the author's final, peer-reviewed manuscript. The published version may be accessed by following the link in the citation at the bottom of the page.

Table VII. Attitudes toward consumerism

1. Manufacturers seem to be more sensitive

1986 sample 2001 sample $\quad p$-value to consumer complaints now than they were

in the past 2.28

0.104

2. When consumers have problems with products they have purchased, it is usually easy to get them fixed 3.14

3. Most business firms make a sincere effort to adjust consumer complaints fairly $\quad 2.64$
2.51
0.184

4. The exploitation of consumers by business firms deserves more attention than it receives

5. Consumerism or the consumer crusade has not been an important factor in changing business practices and procedures

6. Consumerism is an important issue today

7. In the future, consumerism will be more important
2.12
2.47
0.000

Note: All items are measured on a five-point scale where 1 1/4 strongly agree and $51 / 4$ strongly disagree. The Table shows item mean ratings for the two samples along with $p$-values associated with the mean difference tests 